Article

\title{
Effects of Temporal Variation in Long-Term Cultivation on Organic Carbon Sequestration in Calcareous Soils: Nile Delta, Egypt
}

\author{
Manal Alnaimy ${ }^{1}$, Martina Zelenakova ${ }^{2, *}$, Zuzana Vranayova ${ }^{3}$ and Mohamed Abu-Hashim ${ }^{1}$ (D \\ 1 Department of Soil Science, Faculty of Agriculture, Zagazig University, Zagazig 44511, Egypt; \\ dr_manalalnaimy@yahoo.com (M.A.); dr.mabuhashim@gmail.com (M.A.-H.) \\ 2 Department of Environmental Engineering, Faculty of Civil Engineering, Technical University of Kosice, \\ 04200 Kosice, Slovakia \\ 3 Department of Building Facilities, Faculty of Civil Engineering, Technical University of Kosice, 04200 Kosice, \\ Slovakia; zuzana.vranayova@tuke.sk \\ * Correspondence: martina.zelenakova@tuke.sk; Tel.: +421-905-985-765
}

Received: 2 May 2020; Accepted: 29 May 2020; Published: 2 June 2020

\begin{abstract}
Soil carbon sequestration is a riskier long-term strategy for climate mitigation than direct emissions reduction, but it plays a main role in closing carbon emission gaps. Effects of long-term cultivation on soil carbon sequestration were studied at the western edge of the Nile Delta near Alexandria, Egypt. Seven agricultural fields of different ages (0-50 years in use) were selected and compared with the surrounding desert (virgin soil) and desert shrub-land. Samples were taken at three horizons, 0-30, 30-60, and 60-90 cm, and tested for differences in physical and chemical properties. The results of long-term cultivation reveal that the European Commission (EC) value was $11.77 \mathrm{dS} / \mathrm{m}$ in virgin soil, while the EC values decreased to $5.82,4.23,3.74,2.40$, and $2.26 \mathrm{dS} / \mathrm{m}$ after 5 , $10,20,30$, and 50 years of cultivation, respectively. The calcareous rock fraction smaller than $50 \mu \mathrm{m}$ in size revealed another phenomenon, where active calcium carbonate content increased with cultivation practices from $1.15 \%$ (virgin soil) to $5.42 \%, 6.47 \%, 8.38 \%$, and $10.13 \%$ after $5,10,20$, and 30 years of cultivation, respectively, while shrub-land also showed a low amount of active $\mathrm{CaCO}_{3}$ with $1.38 \%$. In fifty years of cultivation, soil bulk density decreased significantly from 1.67 to $1.11 \mathrm{~g} / \mathrm{cm}^{3}$, and it decreased to $1.65,1.44,1.40$, and $1.25 \mathrm{~g} / \mathrm{cm}^{3}$ after $5,10,20$, and 30 years, respectively. These results reveal that the increase in soil carbon stock in the upper $90 \mathrm{~cm}$ amounted to $41.02 \mathrm{tC} /$ ha after five years of cultivation, compared to virgin soil with $13.47 \mathrm{tC} / \mathrm{ha}$. Soil carbon levels increased steeply during the five years of cultivation, with an average rate of $8.20 \mathrm{tC} /$ ha per year in the upper $90 \mathrm{~cm}$. After the first five years of cultivation, the carbon sequestration rate slowed, reaching 4.68, 3.77, 2.58, and $1.93 \mathrm{t} \mathrm{C/ha}$ per year after 10, 20,30, and 50 years, respectively, resulting in sequestration-potential values of 46.78, $75.63,77.43$, and $96.45 \mathrm{t} \mathrm{C/ha}$. These results indicate that potential soil carbon sequestration resembles a logarithmic curve until the equilibrium state between carbon application and decomposition by microorganisms is reached.
\end{abstract}

Keywords: cultivation age; soil organic carbon; climate mitigation; carbon sequestration

\section{Introduction}

Agricultural soils are a potential carbon sink that may be used to mitigate and decrease the global greenhouse effect causing climate changes [1-3]. Agriculture and land-use practices such as cultivation, plowing, and land shifting have always been a major source of greenhouse gas (GHG) emissions $[4,5]$. Soil stores about $1500 \mathrm{Pg}$ of carbon in its upper horizons worldwide $(0-100 \mathrm{~cm})$, which is considered to be more than the amount of carbon found in the atmosphere or in crops [6-8]. The soil may be 
stimulated as a carbon sink by the use of land-use practices that reduce organic matter decomposition rates (no-tillage) and/or by increasing the application rate of organic matter, i.e., using organic fertilizers. Soil carbon content is a function of parent material, vegetation, climate/environment, soil management, and time. In addition, land-use practices reveal an essential factor affecting the soil carbon sink: as land management practices, such as plowing for agriculture purposes, decompose the soil organic matter (SOM), the SOM levels rapidly decrease [9].

Croplands are a major terrestrial $C$ reservoir that can sequestrate a carbon stock of $2500 \mathrm{Gt}$ worldwide, consisting of 1550 and $950 \mathrm{Gt}$ of organic and inorganic carbon, respectively, in its first one-meter depth [10]. Deterioration in this $C$ pool would have substantial effects on future carbon dioxide concentrations in the surrounding environment and, hence, also on GHG emissions [11]. Correlations between the surface-soil organic carbon pool (SOCP), land-use, and site parameters are the main factors in developing soil organic carbon (SOC) models and evaluating their impact on land-use and climate [12]. One study [13] analyzed SOC dynamics in terms of climatic variable impacts on local sequestration rates. Although soil texture, drainage condition, and slope did not correlate well with climatic parameters, these parameters varied in close connection with changes in land-use and SOC. These characteristics are responsible for $50 \%, 51 \%$, and $54 \%$ of SOCP values in forest, grassland, and cropland, respectively [14]. Such variables become significant on a regional scale for assessing SOCP variations in which climatic change is not identified $[15,16]$. The initial role of soil texture in SOC sequestration was attributed to the consistence scale of passive C [17]. Nevertheless, its secondary role was due to its effect on the hydrologic properties of the soil surface [15]. Moreover, [16] showed that land-use had marked effects on the SOCP on a large scale, considering the soil pedon cells that increase with clay content. Transformation in agriculture with the effect of decreasing inputs of organic matter and/or increasing soil erosion leads to a degradation of SOC [18]. Another study [19] observed that this degradation was permanent in the top $30 \mathrm{~cm}$ of soil, in which the SOCP was reduced by $50 \%$, and by $20 \%$ to $30 \%$ in the top $100 \mathrm{~cm}$ horizon. In addition, [3] investigated changes in land-use techniques, which are useful practices for enhancing $\mathrm{C}$ sequestration that would consequently reduce atmospheric $\mathrm{CO}_{2}$ levels. West and Post (2002) [20] reported $20 \pm 12 \mathrm{~g} \mathrm{C} \mathrm{m}^{-2}$ year $^{-1}$ was sequestrated in the upper $30 \mathrm{~cm}$ horizon with crop rotation systems associated with increasing crop numbers. These efficient land management practices lead to increased SOC sequestration, and [21] found that improving cropland management resulted in SOC sequestration increasing from 80 to $208 \mathrm{Tg} C$ year ${ }^{-1}$ $\left(\mathrm{Tg}=10^{12} \mathrm{~g}\right)$. In cultivated lands, [22] also investigated the impact of land-use techniques on SOC sequestration, and found an increase from 60 to $70 \mathrm{Tg} \mathrm{C}$ year $^{-1}$ in carbon potential. Land management changes affecting the SOCP scales could involve temporal and spatial variability, which influences SOC levels to a large extent. Similarly, [10] revealed important changes in SOCP values at a $30-\mathrm{cm}$ soil depth that were associated with land-use changes and influenced by soil texture and drainage.

The carbon sequestration potential of arid soils in Egypt is a relevant issue that has appeared together with land reclamation activities on a large scale. Arid desert soil, compared to other soils, has relatively high potential to act as a carbon sink, as its initial carbon stock is usually minimal [23,24]. While conventional farming practices still apply common methods, reclaimed lands in the northwestern deserts in Egypt are increasingly used for food production. The land was reclaimed using drip irrigation and is commonly fertilized with compost. Over the years, Burg El Arab has expanded in size, and hence, a mosaic of cultivated fields of different ages has gradually emerged, providing a relevant environment for carbon sequestration in such arid soils due to their management over time. SOC sequestration in soils reclaimed using irrigation and compost, considering temporal variations, may offer a methodology for generating carbon credits in desert regions like Egypt. Although the hydro-physical properties and resulting beneficial effects of using compost on soil structure in arid soils have been investigated [25,26], the influence of temporal variations on the SOCP potential in reclaimed soils remains unknown. Cultivation leads to soil development from its natural state to a transformed one through long-term intensive agricultural use $[27,28]$. This was the main aim, especially regarding uncultivated lands with calcareous soils, which is the situation in the northwestern part of Egypt, with soils dominated 
by calcium carbonate. In addition to the overall calcium carbonate content, active calcium carbonate, the separated fraction of calcareous rock smaller than $50 \mu \mathrm{m}$ in size, plays an essential role in forming the soil properties and the soil capacity to enhance its physical properties. This carbonate fraction is susceptible to rapid mobilization, and it is chemically active [29]. Active carbonate influences the extent and reactivity of the surfaces of the carbonates and constitutes an important reserve of exchangeable $\mathrm{Ca}^{2+}$. Exchangeable $\mathrm{Ca}^{2+}$ comes mostly from carbonated rock, whose rate of dissolution depends on the hardness and size of its particles; the dissolution speed increases as the size decreases $[29,30]$. Soil $\mathrm{CaCO}_{3}$ is an important criterion in the soils of the Mediterranean region [31]. Carbonate accumulations follow a sequence of morphologic development, starting as horizon features such as carbonate coats, masses, and fine nodules. Calcareous soils originate mainly from carbonate-rich parent materials.

The objectives of this study are (1) to investigate the development of the soil organic carbon pool (SOCP) in a mosaic of cultivated fields of different ages, with reclaimed arid soils near Alexandria in northwestern Egypt, (2) to trace the effects of cultivation periods over the long term (50 years) on the chemical properties and organic carbon sequestration in soil, which mainly originated from calcareous parent material (geological age), and (3) to determine the carbon sequestration potential in different layers of arid desert soils in Egypt and the impacts on the potential of their physical-chemical properties.

\section{Materials and Methods}

\subsection{Experimental Site Specification}

The study was conducted in the region west of the Nile Delta, in the Burg El Arab catchment area south-west of Alexandria City, Egypt, $\left(31^{\circ} 20^{\backslash} \mathrm{N}, 29^{\circ} 90^{\backslash} \mathrm{E}\right)$ with an area of 34,650 ha, as shown in Figure 1. The region is characterized by Mediterranean climatic conditions, with high oscillations between the minimum and maximum daily temperatures. The results of a three-year climatic data survey (2017-2020) conducted at Burg El Arab Meteorological Station show that the average annual rainfall (mainly in winter seasons) is $210.6 \mathrm{~mm}$. Moreover, the mean annual temperature is $21.4^{\circ} \mathrm{C}$, with a maximum temperature of $35.66^{\circ} \mathrm{C}$ and a minimum temperature of $9.5^{\circ} \mathrm{C}$. The surface of the area is created mainly of various Tertiary and Quaternary sedimentary deposits [32]. The study area is characterized by a series of three parallel Pleistocene limestone ridges, ranging in elevation up to $35 \mathrm{~m}$ and separated by shallow depressions. The Quaternary deposits constitute the main groundwater source in the area. These ridges and depressions in the Burg El Arab area control the groundwater flow pattern. The irrigation water source is El Aqarya Canal, a line branch from El Nubaria Canal, which receives its water directly from the Nile.

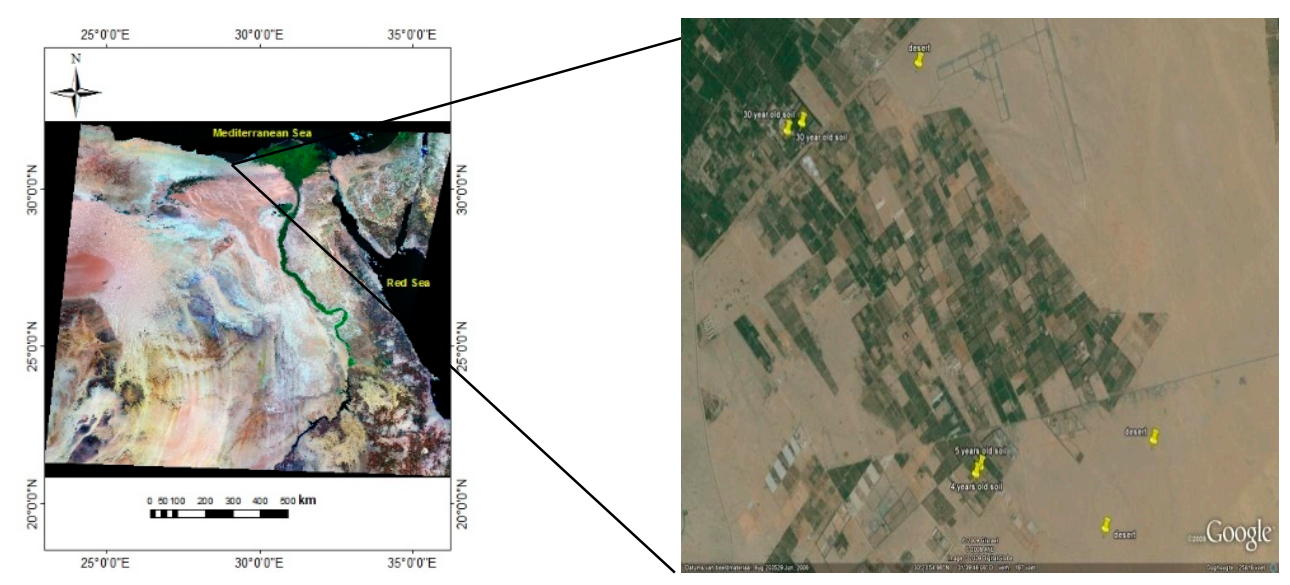

Figure 1. Sample location of the studied arable fields west of the Nile Delta, Burg El Arab, southern Alexandria City, Egypt. 


\subsection{Selected Soil Data and Laboratory Analysis}

Seven arable fields of different ages (Table 1) were selected in the western desert area of the Nile Delta, near Burg El Arab city. Seven soil profiles sites were selected to represent the variations in a mosaic of cultivated fields of different ages, reclaimed using the drip irrigation method. Profile 1 represents the uncultivated soils (control), while Profile 2 represents the soil in zones dominated by shrubs. Profiles 3, 4, 5, 6, and 7(Figure 1) represent the state of cultivated soils after 5, 10, 20, 30, and 50 years.

The soil profile of every field was studied down to a 90-cm depth. The fields were sampled for analysis in three line transects. Each transect consisted of five sample locations where samples were collected at three horizons (0-30, 30-60, and 60-90 cm deep). The representative soil samples for each horizon were air-dried for the physical and chemical analyses. At the indicated locations and soil depths, bulk density samples were prepared for measurements, which were taken by hammering sample rings with a fixed volume $\left(100 \mathrm{~cm}^{3}\right)$ into the soil.

The soil samples were air-dried at room temperature and were ground to pass through a 2-mm sieve. Soil pH (1:2.5) was measured using a Hanna model PH211 microprocessor-based pH-meter. Electrical conductivity (EC) was assessed in soil paste extract using a conductivity meter. For active carbonate determination, exchangeable cations of $\mathrm{Ca}^{2+}$ and total $\mathrm{CaCO}_{3}$ (equivalent carbonate) were measured according to the methods of [33]. Active carbonate (carbonate extractable with ammonium oxalate) was likewise determined according to [33]. Organic matter was determined using the Walkley and Black method [34]; cation exchange capacity (CEC) was determined using the ammonium acetate method [35]; available $\mathrm{N}$ was extracted with $\mathrm{K}_{2} \mathrm{SO}_{4}$ and quantified by means of the steam-distillation procedure using $\mathrm{MgO}$-Devarda alloy according to the Bremner and Keency method, as described by [34]. Available $\mathrm{P}$ was extracted with $0.5 \mathrm{~N} \mathrm{NaHCO}_{3}$ at $\mathrm{pH} 8.5$ [36] and quantified colorimetrically using the ascorbic acid method [37], and available $\mathrm{K}$ was extracted with $1.0 \mathrm{~N}$ ammonium acetate at pH 7.0 and quantified using a flame photometer [38]. Particle-size analysis was performed using the international pipette method [39]. Saturation percentage and soil density calculations were carried out according to [33]. 
Table 1. Physico-chemical properties of different layers in investigated soil after longer cultivation periods.

\begin{tabular}{|c|c|c|c|c|c|c|c|c|c|c|c|c|}
\hline Cultivation Period & Horizon Depth, cm & $\mathrm{pH}(1: 2.5)$ & Coarse Sand \% & Fine Sand \% & Total Sand \% & Silt \% & Clay $\%$ & Texture & Ava. $\mathrm{N}, \mathrm{mg} / \mathrm{kg}$ & Ava. $P, \mathrm{mg} / \mathrm{kg}$ & Ava. $\mathrm{K}, \mathrm{mg} / \mathrm{kg}$ & FC $\%$ \\
\hline \multirow{3}{*}{ Virgin Soil } & $0-30$ & 8.34 & 15.22 & 68.76 & 83.98 & 3.50 & 12.52 & Loamy sand & 5.76 & 2.87 & 31.87 & 8.72 \\
\hline & $30-60$ & 8.41 & 12.76 & 70.22 & 82.98 & 2.50 & 14.52 & Sandy loam & 4.12 & 1.09 & 30.87 & 9.34 \\
\hline & $60-90$ & 8.43 & 8.87 & 71.89 & 80.76 & 1.50 & 17.74 & Sandy loam & 2.67 & 1.00 & 29.32 & 10.27 \\
\hline \multirow{3}{*}{ Desert shrubs } & $0-30$ & 8.26 & 12.22 & 55.76 & 67.98 & 17.40 & 14.62 & Sandy loam & 9.87 & 2.87 & 41.98 & 9.66 \\
\hline & $30-60$ & 8.33 & 13.31 & 51.56 & 64.87 & 15.89 & 19.24 & Sandy clay loam & 3.76 & 1.65 & 38.98 & 9.48 \\
\hline & $60-90$ & 8.37 & 16.74 & 44.76 & 61.50 & 15.78 & 22.72 & Sandy clay loam & 2.11 & 1.58 & 30.55 & 8.49 \\
\hline \multirow{3}{*}{5 years cultivation } & $0-30$ & 8.11 & 12.67 & 46.87 & 59.54 & 14.80 & 25.66 & Sandy clay loam & 11.76 & 5.87 & 62.98 & 15.11 \\
\hline & $30-60$ & 8.13 & 14.22 & 48.76 & 62.98 & 13.60 & 23.42 & Sandy clay loam & 9.87 & 3.67 & 60.98 & 13.78 \\
\hline & $60-90$ & 8.19 & 21.76 & 43.22 & 64.98 & 16.98 & 18.04 & Sandy loam & 3.90 & 2.78 & 46.12 & 10.37 \\
\hline \multirow{3}{*}{10 years cultivation } & $0-30$ & 8.03 & 19.53 & 33.87 & 53.40 & 17.89 & 28.71 & Sandy clay loam & 39.78 & 15.87 & 176.98 & 15.78 \\
\hline & $30-60$ & 8.09 & 21.35 & 35.65 & 57.00 & 24.87 & 18.13 & Sandy loam & 38.33 & 14.87 & 166.76 & 10.94 \\
\hline & $60-90$ & 8.13 & 30.22 & 46.76 & 76.98 & 15.22 & 7.80 & Loamy sand & 29.57 & 10.65 & 140.00 & 4.11 \\
\hline \multirow{3}{*}{20 years cultivation } & $0-30$ & 7.76 & 5.68 & 45.99 & 51.67 & 20.00 & 28.33 & Sandy clay loam & 29.20 & 14.70 & 192.50 & 17.38 \\
\hline & $30-60$ & 7.87 & 8.94 & 41.60 & 50.54 & 20.12 & 29.34 & Sandy clay loam & 25.40 & 14.60 & 191.20 & 17.61 \\
\hline & $60-90$ & 8.15 & 8.58 & 35.98 & 44.56 & 21.44 & 34.00 & Sandy clay loam & 19.33 & 8.54 & 166.00 & 18.67 \\
\hline \multirow{3}{*}{30 years cultivation } & $0-30$ & 7.61 & 18.66 & 30.32 & 48.98 & 19.76 & 31.26 & Sandy clay loam & 44.98 & 18.98 & 189.98 & 18.84 \\
\hline & $30-60$ & 7.72 & 23.14 & 29.76 & 52.90 & 17.45 & 29.65 & Sandy clay loam & 42.87 & 17.87 & 187.44 & 17.99 \\
\hline & $60-90$ & 7.93 & 19.78 & 41.78 & 61.56 & 15.78 & 22.66 & Sandy clay loam & 38.55 & 12.87 & 166.87 & 13.78 \\
\hline \multirow{3}{*}{50 years cultivation } & $0-30$ & 7.27 & 26.75 & 41.23 & 67.98 & 3.12 & 28.90 & Sandy clay loam & 47.14 & 18.50 & 165.50 & 15.95 \\
\hline & $30-60$ & 7.34 & 28.69 & 37.98 & 66.67 & 4.43 & 28.90 & Sandy clay loam & 41.11 & 17.00 & 161.60 & 16.44 \\
\hline & $60-90$ & 8.37 & 22.37 & 38.19 & 60.56 & 4.22 & 35.22 & Sandy clay & 37.89 & 9.34 & 147.65 & 19.22 \\
\hline
\end{tabular}




\subsection{Physicochemical Parameters of Soil Samples and Soil Organic Carbon Pool Calculation}

Soil coarse fraction content (particles $>2 \mathrm{~mm}$ in diameter) was determined according to [40]: gravel content $(\%)=($ weight of coarse materials/weight of coarse and fine materials $) \times 100$.

Calculation of the SOCP was carried out as a parameter of SOC concentration $[3,41]$. The content of soil organic matter (SOM) for each horizon was first converted to SOC percentage by multiplying the $\mathrm{SOM}$ by a factor of $0.58[42,43]$. For each soil horizon, $\mathrm{SOCP}\left(\mathrm{kg} \mathrm{C} \mathrm{m}^{-2}\right)$ was calculated by multiplying the SOC percentage by the soil depth $(30 \mathrm{~cm})$, soil bulk density $\left(\mathrm{Mg} \mathrm{m}^{-3}\right)$, and soil fraction $(<2 \mathrm{~mm}$ in size) [42]:

$$
\mathrm{SOCP}=[\mathrm{L} * \mathrm{~B} \cdot \mathrm{D} * \mathrm{SOC} *(1-\mathrm{F} / 100)] / 10
$$

where SOCP is the soil organic carbon pool for each soil horizon $\left(\mathrm{kg} \mathrm{m}^{-2}\right), \mathrm{L}$ is the thickness of the soil layer $(30 \mathrm{~cm}), \mathrm{SOC}$ is soil organic carbon content (wt \%), F > $2 \mathrm{~mm}$ coarse soil fragment (wt \%), and BD is the soil dry bulk density $\left(\mathrm{Mg} \mathrm{m}^{-3}\right)$.

\section{Results and Discussion}

\subsection{Effect of Cultivation Period on Soil Physico-Chemical Properties}

The results in Table 1 reveal that soil $\mathrm{pH}$ decreased from alkaline in virgin soil (8.39) to slightly alkaline in cultivated soil 8.14, 8.08, 7.93, 7.75, and 7.66 after 5, 10, 20, 30, and 50 years, respectively. This could be attributed to the addition of fertilizers and manures over long periods. Generally, it was observed that $\mathrm{pH}$ values increased in deeper horizons (Table 1) compared to the upper soil horizons, which could be attributed to the movement of soluble salts and increasing calcium carbonate content (parent material). Our results are consistent with [44,45], in that increasing $\mathrm{pH}$ values of alkaline soils need special management practices such as the addition of acidifying materials and gypsum. In addition, the $\mathrm{pH}$ of calcareous soils is inversely proportional to $\mathrm{CO}_{2}$ pressure, and while soils can contain $1 \%$ to $25 \% \mathrm{CaCO}_{3}$ with $\mathrm{pH}$ from 7.6 to 8.4, calcareous soils may have $\mathrm{pH}$ up to 8.6 [46].

With respect to soluble salt content, the data indicate that cultivated soils have lower electrical conductivity (EC) values than uncultivated soil (virgin soil). The results of long-term cultivation reveal that the EC value was $11.77 \mathrm{dS} / \mathrm{m}$ in the virgin soil, and then, the EC values decreased to 5.82 , $4.23,3.74,2.40$, and $2.26 \mathrm{dS} / \mathrm{m}$ after $5,10,20,30$, and 50 years of cultivation, respectively. In addition, the obtained results indicate that the salinity distribution increased in the deeper soil layers compared to the upper layer (Figure 2). On the other hand, the salt distribution in shrub-land soil reveals another phenomenon, i.e., that the upper layer $(0-30 \mathrm{~cm})$ contains high salinity $(13.67 \mathrm{dS} / \mathrm{m})$ compared to the lower soil layers 30-60 and 60-90 cm with 7.51 and $6.11 \mathrm{dS} / \mathrm{m}$, respectively (Figure 2). The decrease in EC values is attributed to continuous leaching processes in light-textured calcareous soils through long cultivation periods, whereby there is less intensive leaching in shrub-land soil [44,45].

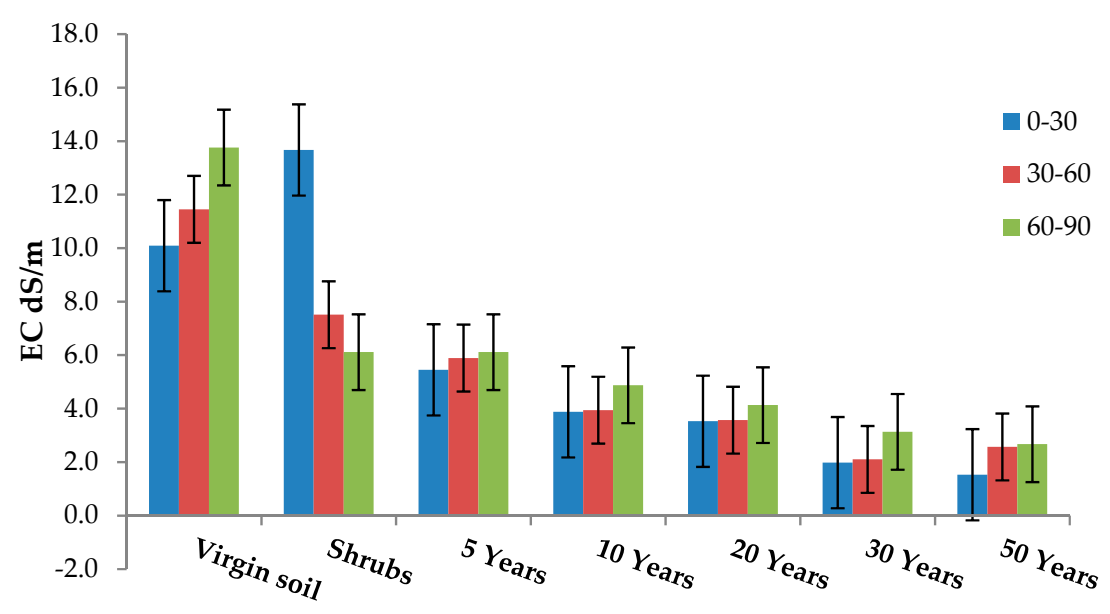

Figure 2. Impact of cultivation period on salinity distribution $(\mathrm{dS} / \mathrm{m})$ in different soil layers. 
Calcium carbonate content is the main indicator of the calcareous soils in northwestern Egypt, and this reveals interesting results about long-term cultivation. $\mathrm{CaCO}_{3}$ content was found to be extremely high $(40.88 \%)$ in the uncultivated soils (virgin soil), while the values of calcium carbonate concentrations were affected by the length of cultivation periods, decreasing to $29.22 \%$ after five years of cultivation (Figure 3). Continuous cultivation in this region has resulted in the $\mathrm{CaCO}_{3}$ content decreasing to moderate values $(25.32 \%)$ after 20 years and low values $(12.76 \%)$ after 50 years of cultivation (Figure 3). This could be attributed to the effect of organic matter decomposition as a consequence of manure application during cultivation. In addition, the distribution of calcium carbonate with depth reveals that the $\mathrm{CaCO}_{3}$ content increased with depth in all the investigated soil samples over the different cultivation periods. In calcareous soils, calcium carbonate was efficiently stored in the deeper layers, and the acidity created through the nitrification process was neutralized through accelerating $\mathrm{CaCO}_{3}$ depletion [47]. Dissolution of $\mathrm{CaCO}_{3}$ via this anthropogenic source of acidity leads to $\mathrm{CO}_{2}$ efflux and loss of $\mathrm{CaCO}_{3}$ from the soil surface [48]. The application of acidifying fertilizers, such as ammonia and sulfur, reduced soil carbonate content during the cultivation process [49]. These conclusions are in agreement with the results of [50], who found significant differences in soil carbonate content between continuously cropped fields.

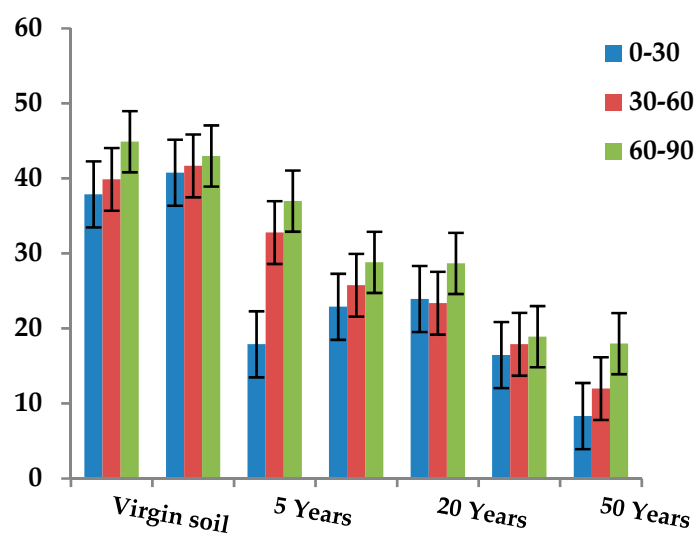

Figure 3. Calcium carbonate distribution at different soil depths in successive cultivation periods.

In addition to the calcium carbonate content and its impact on the physico-chemical properties of calcareous soils, the active calcium carbonate attributed to the fraction of calcareous rock smaller than $50 \mu \mathrm{m}$ in size revealed another phenomenon (Figure 4). Active calcium carbonate contents increase with the duration of cultivation practices, whereby the concentration increased from $1.15 \%$ in virgin soil to $5.42 \%, 6.47 \%, 8.38 \%$, and $10.13 \%$ after $5,10,20$, and 30 years of cultivation, respectively (Figure 4 ). Shrub-land showed low amounts of active $\mathrm{CaCO}_{3}$, with just $1.38 \%$. Furthermore, the results indicate that the differences in active $\mathrm{CaCO}_{3}$ distribution among the investigated layers were pronounced, with higher values of active $\mathrm{CaCO}_{3}$ in the upper layer $(0-30 \mathrm{~cm})$ than in the deeper layer $(60-90 \mathrm{~cm})$. Carbonate content is a true reflection of the effect of parent material of the soil. An absence of any distinct calcic horizons reflects the low intensity of soil-forming processes and the relatively short time of soil formation, as well as the dominance of the parent material [46]. Ref. [31] reported that soils under arid or semiarid conditions in the northern Mediterranean zone are mostly calcareous. Ref. [51] found that such land surfaces are mainly represented by Holocene deposits of coastal sand dunes, old lagoonal and alluvial accretions, and Pleistocene oolitic limestone ridges. 


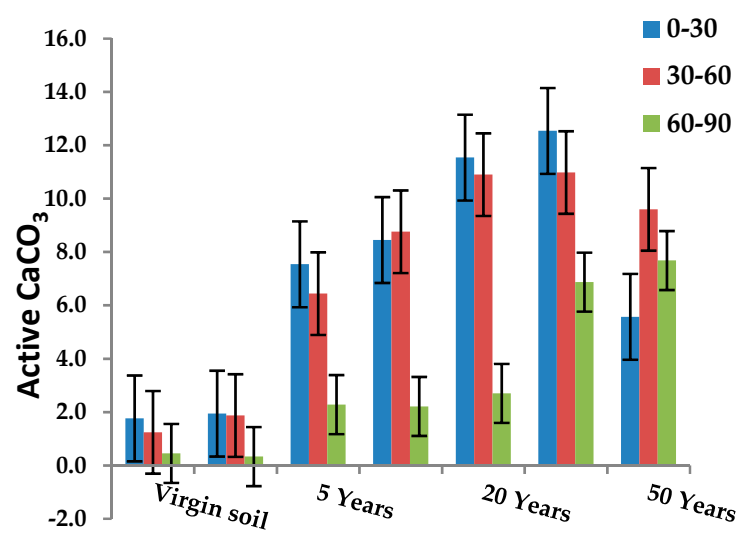

Figure 4. Active calcium carbonate in successive cultivation periods.

Cation exchange capacity was observed in cultivated soils compared to virgin soil (Figure 5). The results reveal that the CEC content of virgin soil was $6.20 \mathrm{cmolcl}^{-1}$, while the CEC values with increasing cultivation duration were 13.65, 24.28, 30.88, and $31.40 \mathrm{cmolcl}^{-1}$ after 5, 10, 30, and 50 cultivation years, respectively. In addition, the distribution of CEC values with soil depth in successive cultivation periods reveals that the CEC value was higher at the soil surface and decreased with soil depth, cation exchange capacity of shrub-land soil was lower than that in the cultivated surrounded soil with $6.78 \mathrm{cmolcl}^{-1}$, and its content at the soil surface was higher than in the deeper soil layers (Figure 5). The increase in cation exchange capacity in cultivated soils over longer periods was found to be related to clay and organic matter content. The obtained results are in agreement with those of [52], namely that CEC results are in parallel with the cultivation activities in the reclaimed desert areas and are considered as an indicator of soil fertility in supplying nutrients. High CEC indicates high clay and organic matter content since many plant nutrients are positively charged ions, so they are adsorbed on the colloidal surfaces of clay and organic matter [45].

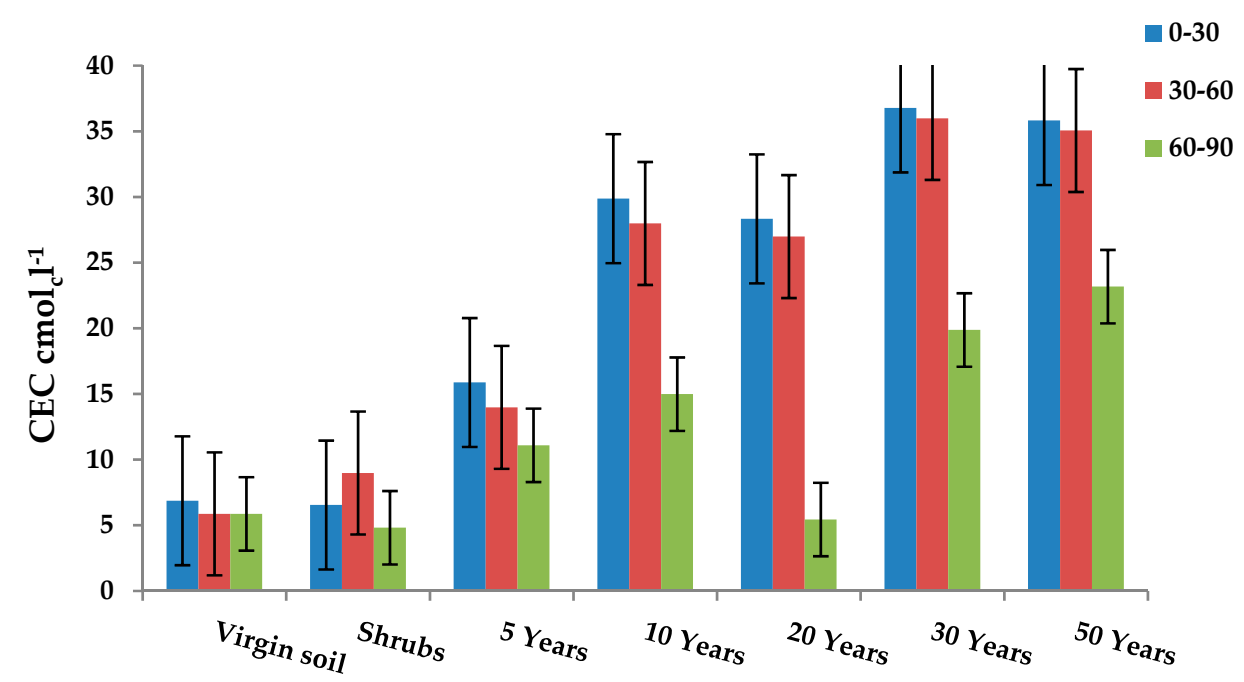

Figure 5. Impact of cultivation period on cation exchange capacity (CEC) $\mathrm{cmolcl}^{-1}$ in different soil layers.

Soil bulk density results revealed that at a depth of $0-30 \mathrm{~cm}$, it was significantly affected by agricultural practices (Figure 6). In 50 years of cultivation, the bulk density decreased significantly from 1.67 to $1.11 \mathrm{~g} / \mathrm{cm}^{3}$, while it declined to $1.65,1.44,1.40$, and $1.25 \mathrm{~g} / \mathrm{cm}^{3}$ after $5,10,20$, and 30 years, respectively. The same phenomena were observed in the second horizon $(30-60 \mathrm{~cm})$, i.e., that the soil bulk density decreased significantly from $1.66 \mathrm{~g} / \mathrm{cm}^{3}$ in virgin soil to $1.11 \mathrm{~g} / \mathrm{cm}^{3}$ in cultivated land 
after 50 years. At a depth of $60-90 \mathrm{~cm}$, however, the bulk density was not significantly affected by agricultural practices (Figure 6).

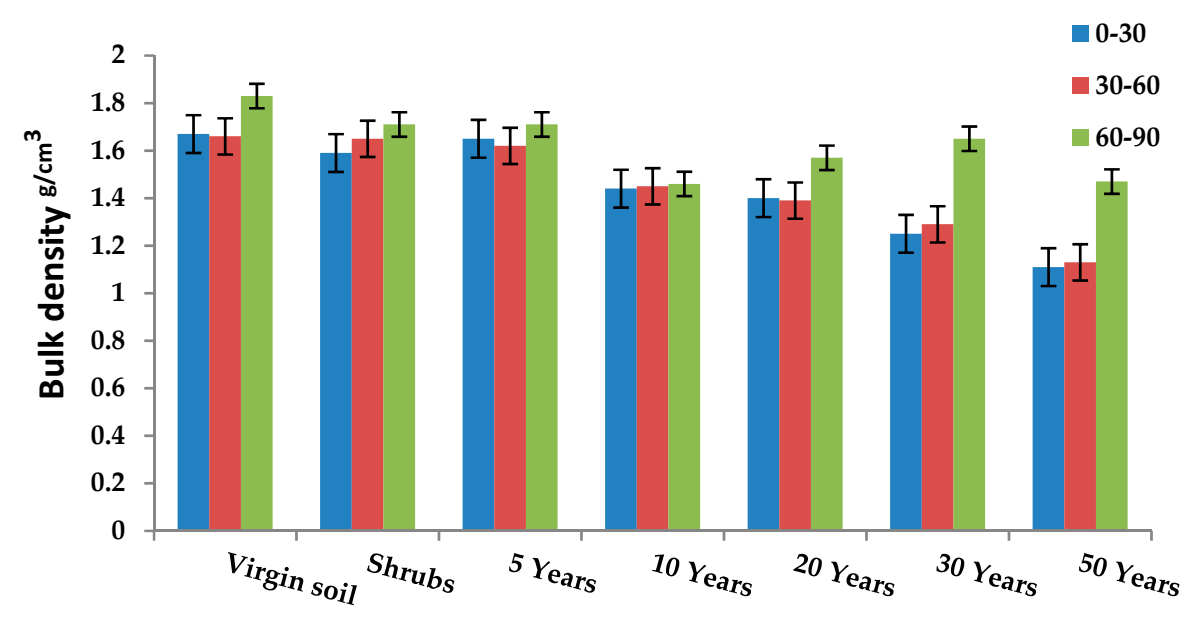

Figure 6. Impact of cultivation period on soil bulk density $\left(\mathrm{g} / \mathrm{cm}^{3}\right)$ in different soil layers.

\subsection{Effect of Cultivation Period on Soil Organic Carbon Sequestration}

\subsubsection{Organic Carbon Content}

The organic carbon content of virgin soil close to the city of Burg El Arab was $0.12 \%(0-30 \mathrm{~cm})$, whereas the fields which were cultivated for $5,10,20,30$, and 50 years contained $0.42 \%, 0.55 \%$, $0.92 \%, 0.98 \%$, and $1.22 \%$ of carbon, respectively, in the upper $(0-30 \mathrm{~cm})$ layer of the soil. The second horizon $(30-60 \mathrm{~cm})$ showed interesting results, namely that the carbon content increased from $0.09 \%$ in uncultivated soil (virgin land) to $0.41 \%, 0.38 \%, 0.87 \%, 0.96 \%$, and $1.10 \%$ in the cultivated lands after 5, 10, 20, 30, and 50 years, respectively. However, in the deeper layer $(60-90 \mathrm{~cm})$, the increase in carbon content was not significantly linked with the agricultural practices or the period of cultivation (Figure 7). In arid and semiarid regions, SOC plays an essential role in the global carbon cycle and climate change [2]. The results obtained here are in agreement with the findings of [53,54], who established that SOC stocks were greater in agricultural land than in nonagricultural land.

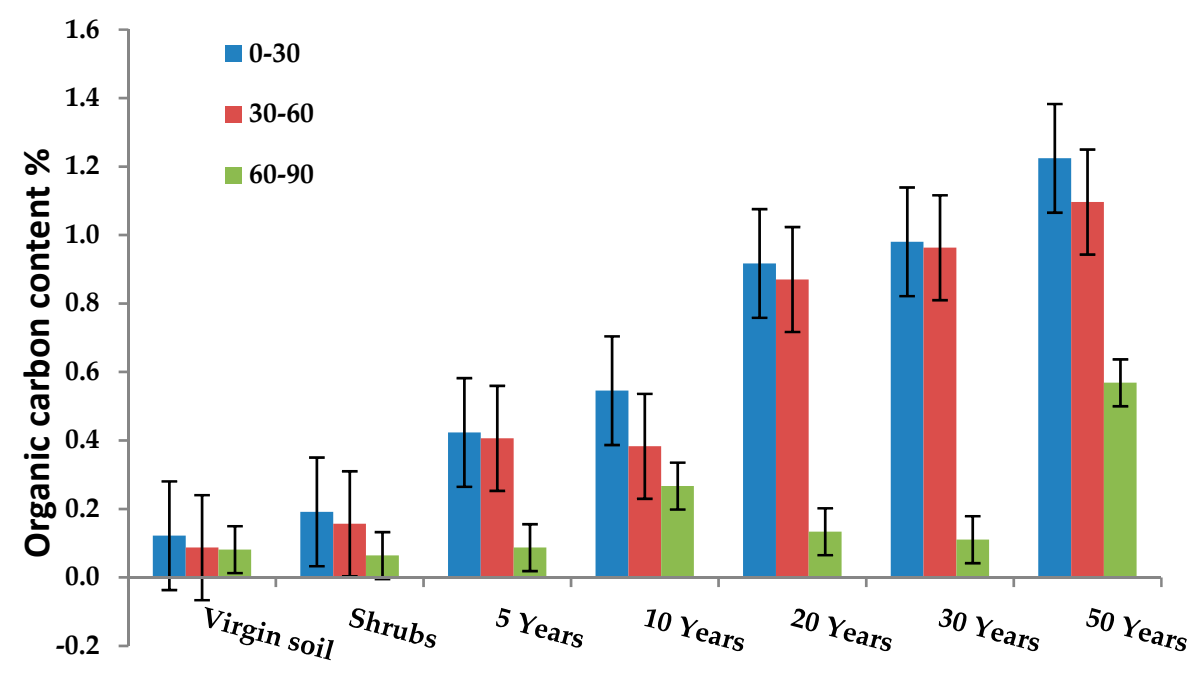

Figure 7. Impact of cultivation period on organic carbon distribution in different soil layers. 


\subsubsection{Potential Soil Carbon Sequestration}

The effects of successive cultivation periods acted significantly on soil bulk density (Figure 6) and organic carbon content, which is mainly used for calculations of SOC stocks. The results in Figure 8 reveal that the increase in soil carbon in the upper $90 \mathrm{~cm}$ amounted to $41.02 \mathrm{t}$ of $\mathrm{C} /$ ha after five years of cultivation compared to the virgin soil content of $13.47 \mathrm{t}$ of $\mathrm{C} / \mathrm{ha}$. During five years of cultivation, the carbon levels increased steeply, with an average rate of $8.20 \mathrm{tC} /$ ha per year in the upper $90 \mathrm{~cm}$. After the first five years of cultivation, the carbon sequestration rate slowed, reaching 4.68, 3.77, 2.58, and $1.93 \mathrm{t} \mathrm{C/ha} \mathrm{per} \mathrm{year} \mathrm{after} \mathrm{10,} \mathrm{20,30,} \mathrm{and} 50$ years, respectively, resulting in sequestration potential values of 46.78, 75.63, 77.43, and $96.45 \mathrm{tC} /$ ha (Figure 8). These results indicate that potential soil carbon sequestration resembles a logarithmic curve (Figure 8) until an equilibrium state between carbon application and decomposition by microorganisms is reached.

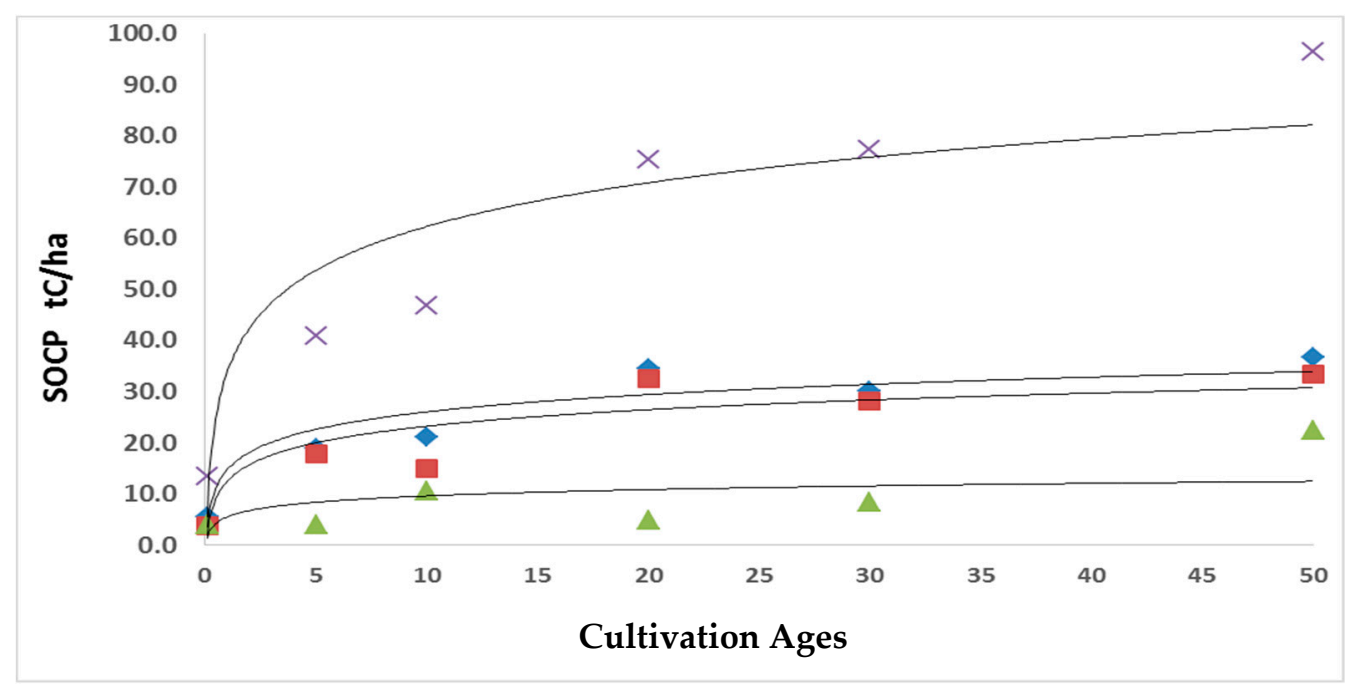

Figure 8. Potential soil carbon sequestration trend under the influence of successive cultivation periods.

These results are consistent with the findings of $[3,18,54]$, in particular, that SOC stocks were greater in agricultural land than in nonagricultural land in arid and semiarid regions. The impact of agricultural management on SOC plays an important role in the global carbon cycle and climate change [53]. The increase in soil carbon sequestration initially takes place in the upper 0-30 cm of the soil and then shifts towards deeper soil layers. After five years of cultivation, the soil carbon sink was $18.86 \mathrm{t}$ of $\mathrm{C} /$ ha compared to the lower layer $(60-90 \mathrm{~cm})$ amount of $4.02 \mathrm{t}$ of $\mathrm{C} / \mathrm{ha}$. The same results were also reported for the next 50 years of cultivation. After 10, 20, 30, and 50 years of cultivation, the SOCP values were $21.20,34.66,30.20$, and $36.68 \mathrm{t}$ of $\mathrm{C} / \mathrm{ha}$, respectively, in the upper layer $(0-30 \mathrm{~cm})$ compared to the deeper layer $(60-90 \mathrm{~cm})$, in which SOCP values were $10.52,4.91,8.47$, and $22.56 \mathrm{t}$ of $\mathrm{C} /$ ha after 10 , 20, 30, and 50 years of cultivation (Figure 8). Organic $C$ content is important in determining the soil chemical properties, and it directly and indirectly influences soil properties in general $[2,9,55]$.

The Kyoto Protocol states that carbon sinks and sources should be accounted for, "taking into account uncertainties, verifiability, and transparency in reporting". However, [11] identified the issues surrounding the monitoring and verification of soil carbon sequestration. The significant generic problem of changes in terrestrial biospheric carbon relates to $\mathrm{CO}_{2}$ resolution (the smallest detectable change). The rate of change in biospheric carbon pools is slow, especially in relation to the pool size, and measurable changes in carbon stock are not easily achieved for the larger soil carbon pools [4]. In a recent paper, the minimum detectable variation in soil organic carbon potential was calculated as a function of cultivation duration and sample size for SOC changes, and this is consistent with the findings of $[56,57]$. 


\section{Conclusions}

Efforts have been made to increase the productivity of newly-reclaimed soil in order to meet the urgent food demand from the growing world population. The productivity of such soils is directly linked to their inherent quality and to the new properties that have been developed by cultivation over a specific period of time. Improved agricultural management often has a range of other environmental and economic benefits in addition to climate mitigation potential, and such "win-win" strategies to improve soil carbon storage are attractive and should be implemented as part of integrated sustainability policies. This study demonstrates that carbonate content is a true reflection of the effect of parent material on soil characteristics and that soil active calcium carbonate content increases with long-term cultivation practices, while shrub-land tends to have lower amounts of active $\mathrm{CaCO}_{3}$. The effects of the cultivation period significantly affect soil carbon sink levels during the first cultivation years. Then, the increase in carbon sequestration declines with further continuous cultivation, and this soil carbon sink potential resembles a logarithmic curve as a function of agricultural duration. Therefore, due to the strong influence of land management and land-use on carbon sequestration, greater precision would be obtained if SOC sequestration on a regional scale was identified for the different land-use categories.

Author Contributions: This research article includes several contributions. Conceptualization was prepared by M.A.-H. M.A. performed the field survey. The data sample analysis and the investigations were prepared and analyzed by M.A. and M.A.-H. The original draft preparation of the article was done by M.A., M.A.-H., and M.Z. Review and editing of the text were finalized by M.A. and Z.V. The supervision and funding acquisition were supported by M.A.-H. and Z.V. The final version of the article was revised by M.A.-H. and M.Z. All authors have read and agreed to the published version of the manuscript.

Funding: This research received no external funding.

Acknowledgments: This study represents efficient scientific participation between the scientific institutions in two countries (Egypt, Slovak Republic). Special thanks to the staff of the Soil Science Department at the Faculty of Agriculture, Zagazig University, for helping in the field survey, and to the various facilities for the lab analysis. The authors are thankful to have been supported in this project by the Ministry for Education of the Slovak Republic with VEGA grant 1/0217/19 "Research of Hybrid Blue and Green Infrastructure as Active Elements of a Sponge City" and a project grant from the Slovak Research and Development Agency APVV-18-0360 "Active hybrid infrastructure towards a sponge city".

Conflicts of Interest: The authors declare no conflict of interest.

\section{References}

1. Lal, R. Desertification Control to Sequester Carbon and Reduce Net Emissions in the United States. Arid Lands 2001, 49. Available online: https://cals.arizona.edu/OALS/ALN/aln49/lal.html (accessed on 2 June 2020).

2. Lal, R. Soil Carbon Sequestration Impacts on Global Climate Change and Food Security. Science 2004, 304, 1623-1627. [CrossRef]

3. Abu-hashim, M.; Elsayed, M.; Belal, A.E. Effect of land-use changes and site variables on surface soil organic carbon pool at Mediterranean Region. J. Afr. Earth Sci. 2016, 114, 78-84. [CrossRef]

4. IPCC. Climate Change 2007: Mitigation of Climate Change; Working Group III Contribution to the Fourth Assessment Report of the Intergovernmental Panel on Climate Change; Meyer, Ed.; Cambridge University Press: Cambridge, UK; New York, NY, USA, 2007.

5. Mohamed, E.; Abu-hashim, M.; AbdelRahman, M.; Schütt, B.; Lasaponara, R. Evaluating the effects of the human activities over the last three decades On the Soil Organic Carbon Pool Using Satellite imagery and GIS techniques in the Nile Delta area, Egypt. Sustainability 2019, 11, 2644. [CrossRef]

6. Batjes, N.H. Mitigation of Atmospheric $\mathrm{CO}_{2}$ Concentrations by Increased Carbon Sequestration in the Soil. Biol. Fertil. Soils 1998, 27, 230-235. [CrossRef]

7. Sombroek, W.G.; Nachtergale, F.O.; Hebel, A. Amounts, Dynamics and Sequestering of Carbon in Tropical and Subtropical Soils. Ambio 1993, 22, 417-426.

8. FAO. Soil Carbon Sequestration for Improved Land Management; FAO: Rome, Italy, 2001.

9. Abu-hashim, M.; Mohamed, E.; Belal, A.E. Land-use Changes and Site Variables on the Soil Organic Carbon Pool: The Potential Application for the MENA Region. Adv. Env. Res. 2017, 55, 65-100. 
10. Tan, Z.X.; Lal, R.; Smeck, N.E.; Calhoun, F.G. Relationships between soil organic carbon pool and site variables in Ohio. Geoderma 2004, 121, 187-195. [CrossRef]

11. Smith, P.; Fang, C.; Dawson, J.J.C.; Moncrieff, J.B. Impact of global warming on soil organic carbon. Adv. Agron. 2008, 97, 1-43.

12. Post, W.M.; King, A.W.; Wullschleger, S.D. Soil organic matter models and global estimates of soil organic carbon. In Evaluation of Soil Organic Matter Models. NATO-ASI Series I: Global Environmental Change; Poulson, D.S., Smith, P., Smith, J.U., Eds.; Springer: Berlin/Heidelberg, Germany, 1996; Volume 38, pp. 201-222.

13. Jenny, H. The Soil Resource: Origin and Behavior; Springer: New York, NY, USA, 1980; p. 377.

14. Homann, P.S.; Sollins, P.; Chappell, H.N.; Strangenberger, A.G. Soil organic carbon in a mountainous, forested region: Relations to site characteristics. Soil Sci. Soc. Am. J. 1995, 59, 1468-1475. [CrossRef]

15. Schimel, D.S.; Braswell, B.H.; Holland, E.A.; McKeown, R.; Ojima, D.S.; Painter, T.H.; Parton, W.J.; Townsend, A.R. Climatic, edaphic, and biotic controls over storage and turnover of carbon in soils. Glob. Biogeochem. 1994, 8, 279-293. [CrossRef]

16. Lantz, A.M.; Lal, R.; Kimble, J.M. Land-use effects on soil carbon pools in three major land resource areas of Ohio. In Agricultural Practices and Policies for Carbon Sequestration in Soil; Kimble, J.M., Lal, R., Follett, R.F., Eds.; Lewis Publishers: Boca Raton, FL, USA, 2002; pp. 165-175.

17. Parton, W.J.; Schimel, D.S.; Ojima, D.S.; Cole, C.V. A general model for soil organic carbon dynamics: Sensitivity to litter chemistry, texture and management. In Quantitative Modeling of Soil Forming Processes; Bryant, R.B., Ed.; Soil Science Society of America: Madison, WI, USA, 1994; pp. 147-168.

18. Lal, R. Soil erosion and the global carbon budget. Environ. Int. 2003, 29, 437-450. [CrossRef]

19. Post, W.M.; Kwon, K.C. Soil carbon sequestration and land-use: Processes and potential. Glob. Change Biol. 2000, 6, 317-327. [CrossRef]

20. West, T.O.; Post, W.M. Soil organic carbon sequestration rates by tillage and crop rotation: A global data analysis. Soil Sci. Soc. Am. J. 2002, 66, 1930-1946. [CrossRef]

21. Lal, R.; Follett, R.F.; Kimble, J.M.; Cole, C.V. Managing U.S. cropland to sequester carbon in soil. J. Soil Water Conserv. 1999, 54, 374-381.

22. Sperow, M.; Eve, M.; Paustian, K. Potential soil C sequestration on U.S. agricultural soils. Climat. Changes 2003, 57, 319-339. [CrossRef]

23. Chapin Metz, H. Egypt: A Country Study; GPO for the Library of Congress: Washington, DC, USA, 1990.

24. Pautsch, G.R.; Adbelrahman, A.H. Effects of Egyptian Economic Reforms: The Horticultural Sector. Food Policy 1998, 23, 199-210. [CrossRef]

25. Wanas, S.A.; Omran, W.M. Advantages of Applying Various Compost Types to Different Layers of Sandy Soil: 1. Hydro-Physical Properties. J. Appl. Sci. Res. 2006, 2, 1298-1303.

26. Wahba, M.M. Influence of Compost on Morphological and Chemical Properties of Sandy Soils, Egypt. J. Appl. Sci. Res. 2007, 3, 1490-1493.

27. Zhou, W.; Lv, T.F.; Chen, Y.; Westby, A.P.; Ren, W.J. Soil physicochemical and biological properties of paddy-upland rotation: A review. Sci. World J. 2014, 2014, 8. [CrossRef]

28. Kuzyakov, Y.; Zamanian, K. Reviews and syntheses: Agropedogenesis-Humankind as the sixthsoil-forming factor and attractors of agricultural soil degradation. Biogeosciences 2019, 16, 4783-4803. [CrossRef]

29. Wild, A. Russell's Soil Conditions and Plant Growth; Longman Group UK Limited: London, UK, 1988.

30. Breemen, N.V.; Buurman, P. Soil Formation; Kluwer Academic Publishers: Dordrecht, The Netherlands; Boston, MA, USA, 1998.

31. Schoeneberger, P.J.; Wysocki, D.A.; Benham, E.C. Field Book for Describing and Sampling Soils; Natural Resources Conservation Service, National Soil Survey Center: Lincoln, The Netherland, 2011; version 3.0.

32. Gindi, A.; Abd-Alla, M.A. Stable isotopes and microfacies of the Middle Miocene Marmarica Formation, north Western Desert, Egypt. Egypt. J. Geol. 2000, 44, 109-125.

33. Klute, A. Water retention: Laboratory methods. In Methods of SOIL Analysis. Part 1, 2nd ed.; Klute, A., Ed.; Agronomy Monograph; ASA and SSSA: Madison, WI, USA, 1986; Volume 9, pp. 635-662.

34. Black, C.A.; Evans, D.D.; Ensminger, L.E.; White, J.L.; Clarck, F.E. Methods of Soil Analysis; American Society of Agrononomy: Madison, WI, USA, 1965.

35. Jackson, M.L. Soil Chemical Analysis; Prentice Hall, Inc., Englewood Cliffs: Upper Saddle River, NJ, USA, 1973.

36. Olsen, S.R.; Cole, F.S.; Dean, L.A. Estimation of Available Phosphorus in Soils by Extraction with Sodium Bicarbonate; US Department of Agriculture: Washington, DC, USA, 1954; pp. 9391-9399. 
37. Watanabe, F.S.; Olsen, S.R. Test of an ascorbic acid method for determining phosphorus in water and $\mathrm{NaHCO} 3$ extracts from soil. Soil Sci. Soc. Am. Proc. 1965, 29, 677-678. [CrossRef]

38. Cottenie, A.; Verloo, M.; Kieken, L.; Velgh, G.; Camerlynek, R. Chemical Analysis of Plant and Soils; Laboratory of Analytical and Agrochemistry, Gent State Univiversity: Gent, Belgium, 1982.

39. Gee, G.W.; Bauder, J.W. Particle size analysis. In Methods of Soil Analysis. Part 1; Klute, A., Ed.; American Society of Agronomy: Madison, WI, USA, 1986; pp. 383-409.

40. Soil Survey Staff. Soil Survey Laboratory Methods Manual; USDA Soil Survey Invest. Rep. 42, Version 4.0; USDA: Washington, DC, USA, 2004.

41. Lal, R.; Kimble, J.M.; Follett, R.F.; Cole, C.V. The Potential of U.S. Cropland to Sequester Carbon and Mitigate the Greenhouse Effect; Ann Arbor Science Publishers: Chelsea, MI, USA, 1998.

42. Tan, Z.X.; Lal, R.; Smeck, N.E.; Calhoun, F.G.; Slater, B.K.; Parkinson, B.; Gehring, B. Taxonomic and geographic distribution of soil organic carbon pools in Ohio. Soil Sci. Soc. Am. J. 2004, 68, 1896-1904. [CrossRef]

43. Tan, Z.X.; Lal, R. Carbon sequestration potential estimates with changes in land use and tillage practice in Ohio, USA. Agric. Ecosyst. Environ. 2005, 111, 140-152. [CrossRef]

44. Abdelrazek, S.A.E. Effect of Cultivation Periods and Farming Practices on Sustainable Soil Health in Some New Reclaimed Soils. Master's Thesis, Faculty of Agriculture, Ain Shams University, Ain Shams, Egypt, 2007.

45. Ahmed, H.M.; El-Maaz, E.; Esmaeil, M. Improvement of calcareous soil chemical properties and its productivity as affected by farming methods and organic manures applications. J. Soil Sci. Agric. Eng. 2015, 6, 1563-1575. [CrossRef]

46. Tantawy, M.F.I.; Abou Hussien, E.A.; Ahmed, M.A.; Ali, A.A. Relative changes of chemical properties of calcareous soils treated by organic acids under different salinity levels of irrigation water. J. Soil Sci. Agric. Eng. 2012, 3, 1017-1032. [CrossRef]

47. Sanderman, J. Can management induced changes in the carbonate system drive soil carbon sequestration? A review with particular focus on Australia. Agric. Ecosyst. Environ. 2012, 155, 70-77. [CrossRef]

48. Chmiel, S.; Hałas, S.; Głowacki, S.; Sposob, J.; Maciejewska, E.; Trembaczowski, A. Concentration of soil $\mathrm{CO}_{2}$ as an indicator of the decalcification rate after liming treatment. Int. Agrophys. 2016, 30, 143-150. [CrossRef]

49. Bughio, M.A.; Wanga, P.; Meng, F.; Qing, C.; Kuzyakov, Y.; Wang, X.; Junejo, S.A. Neoformation of pedogenic carbonates by irrigation and fertilization and their contribution to carbon sequestration in soil. Geoderma 2016, 262, 12-19. [CrossRef]

50. Mikhailova, E.A.; Post, C.J. Effects of land use on soil inorganic carbon stocks in the Russian Chernozem. J. Environ. Qual. 2006, 35, 1384-1388. [CrossRef] [PubMed]

51. Zahran, A.A. Geotechnical study of carbonate rocks on the area between Alexandria and El Alamein along the Mediterranean Sea Coast of Egypt. Assiut Univ. Bull. Environ. Res. 2008, 11, 12-24.

52. El-Khodre, A.S.; Bedaiwy, M.N.A. Experimental characterization of physio-chemical, hydrdynamic and mechanical properties of two typical Egyptian soils. Tishreen Univ. J. Res. Sci. Stud. Biol. Sci. 2008, 30, 169-191.

53. Lal, R.; Kimble, J.M. What Do We Know and What Needs to be Known and Implemented for C Sequestration in Tropical Ecosystems. In Global Climate Change and Tropical Ecosystems; Lal, R., Kimble, J.M., Stewart, B.A., Eds.; Lewis Publishers: Boca Raton, FL, USA, 2000; pp. 417-431.

54. Wang, J.P.; Wang, X.J.; Zhang, J.; Zhao, C.Y. Soil organic and inorganic carbon and stable carbon isotopes in the Yanqi Basin of northwestern China. Eur. J. Soil Sci. 2015, 66, 95-103. [CrossRef]

55. Mohamed, E.S.; Abu-Hashim, M.; Belal, A.A. Sustainable Indicators in Arid Region: Case Study-Egypt. In The Handbook of Environmental Chemistry; Springer: Berlin/Heidelberg, Germany, 2018.

56. Garten, C.T., Jr.; Wullschleger, S.D. Soil Carbon Inventories under a Bioenergy Crop (Switchgrass): Measurement Limitations. J. Environ. Qual. 1999, 28, 1359-1365. [CrossRef]

57. Alnaimy, M.A. Influence of Pedo-Chemical Transformations and Anthropogenic Interferences on the Development of Some Soils in Egypt. Ph.D. Thesis, Faculty of Agriculture, Zagzig University, Zagazig, Egypt, 2019.

(C) 2020 by the authors. Licensee MDPI, Basel, Switzerland. This article is an open access article distributed under the terms and conditions of the Creative Commons Attribution (CC BY) license (http://creativecommons.org/licenses/by/4.0/). 